\title{
Environmental analysis of organic waste treatment focusing on composting scenarios
}

\author{
Luiza S.B.L. Oliveira ${ }^{a}$, Deborah S.B.L. Oliveira ${ }^{a}$, Barbara Stolte Bezerra ${ }^{\text {b, *, }}$ \\ Bárbara Silva Pereira ${ }^{\mathrm{c}}$, Rosane Aparecida Gomes Battistelle ${ }^{\mathrm{b}}$ \\ a College of Engineering, University of South Florida, United States \\ ${ }^{\mathrm{b}}$ UNESP - Univ. Estadual Paulista, Engineering School of Bauru, Bauru Campus, Brazil \\ ${ }^{\text {c } U N E S P ~-~ U n i v . ~ E s t a d u a l ~ P a u l i s t a, ~ I n d u s t r i a l ~ E n g i n e e r i n g, ~ B a u r u ~ C a m p u s, ~ B r a z i l ~}$
}

\section{A R T I C L E I N F O}

\section{Article history:}

Received 5 February 2016

Received in revised form 18 August 2016

Accepted 19 August 2016

Available online 28 August 2016

\section{Keywords:}

Composting

Organic waste

Home composting

LCI

LCA

\begin{abstract}
A B S T R A C T
The correct disposal of the waste generated by human activities is one of the prevalent challenges that the world faces towards a sustainable development. The lack of suitable sites and the high cost of waste treatment have persuaded many municipalities to implement a policy for integrated waste management, which includes measures such as, source reduction, reuse, recycling, composting and final disposal in landfill. This study examined the alternatives for composting of the organic waste generated in the city of Bauru, in the state of São Paulo, which does not have a composting plant, and analyzed the environmental impacts of seven scenarios: current situation, in which all organic waste is disposed at the landfill; dispatch of the organic waste generated in the city to the closest municipality having a composting plant; construction of a composting plant in Bauru; use of home composting for $10 \%, 25 \%, 60 \%$ and $90 \%$ of organic waste. The method consisted of literature review, data collection among the company responsible for the waste management in the municipality, and the Life Cycle Assessment of the scenarios through the software IWM-2 for the Life Cycle Inventory and Recipe2008 conversion factors for the following impact categories: climate change, ozone depletion, particulate matter formation, and human and freshwater toxicity. The results showed that home composting must be followed by a reduction in the organic waste collection days, in order to have a positive effect in the greenhouse emissions derived from transportation and collection. Also home composting has a greater potential to reduce carbon dioxide equivalent emissions per mass of waste composted in comparison with composting plants. The use of transfer station can have a positive effect on composting plants that are located in other municipalities.
\end{abstract}

(c) 2016 Elsevier Ltd. All rights reserved.

\section{Introduction}

The lack of suitable sites for the proper waste disposal and the rise of the costs for waste treatment have prompted the Brazilian government to establish the National Solid Waste Policy (PNRS) in 2010, which brought together efforts from Federal and state governments, municipalities, productive sector and civil society, in search for solutions to the problems caused by waste disposal (Brasil, 2010). This policy is based on an integrated management system that encompasses actions such as, source reduction, reuse,

\footnotetext{
* Corresponding author. Av. Eng. Luiz Edmundo Carrijo Coube, no 14-01, Vargem Limpa, CEP 17.033-360, Bauru, São Paulo, Brazil.

E-mail address: barbarabezerra@feb.unesp.br (B.S. Bezerra).
}

recycling, and composting (Silva et al., 2009).

From an environmental point of view, the composting process is considered one of the most suitable alternatives to manage and treat organic solid waste (Shen et al., 2012; Scoton et al., 2016). Composting provides the recycling of nutrients, and the consequent reuse of the organic fraction of the waste, thus reducing environmental pollution.

In the industrial sector, composting has been widely studied, and the number of Recycling and Composting Units (RCU) implanted for the treatment of waste has increased in recent years, because it has advantages such as, the adequate control of process variables (humidity, temperature, oxygen content, etc.) and the treatment of exhaust gases. Therefore, composting, in a large scale, requires a significant investment in transportation, energy and facilities (Martins, 2012). 
An even better alternative to large scale composting is minicomposting or home composting, used for small amounts of waste, as it has many advantages such as: reducing the amount of waste sent to composting plants and landfills; reducing the environmental impact of the slurry produced by the deposition of organic material in landfills; strengthening environmental awareness and social responsibility of the population; low operating costs; no need for transportation; and reduced occupation of space. However, to date there are very few technical and scientific studies about home composting (Amlinger et al., 2008; Chanakya et al., 2007), despite it being a plausible proposal to manage household waste (Martínez-Blanco et al., 2010).

Studies comparing industrial composting to home composting have focused on their environmental impacts, particularly the energy consumed and the greenhouse gases emitted (Adhikari et al., 2013; Colón et al., 2010). Comparing the environmental impacts, home composting has advantages, such as the dispensability of the collection and transportation of organic waste. However, it also has some environmental concerns regarding the absence of gas treatment systems (Andersen et al., 2012). The work of Colón et al. (2010) pointed out that the fabrication of the composter is the element that most causes environmental impact in home composting, and the use of recycled plastic could minimize its impact.

However, in industrial composting higher consumption values of transport, energy, water, infrastructure, waste and emissions of volatile organic compounds are also involved. This presents home composting as an attractive and complementary alternative to industrial composting in low population density areas (Colón et al., 2010).

The vehicles on roads are the main contributors to emissions of greenhouse gases (GHG), particularly $\mathrm{CO}_{2}$. In 2010, worldwide emissions from road traffic accounted for $16.4 \%$ of the total $\mathrm{CO}_{2}$ emission. Several countries made efforts to reduce emission of greenhouse gases such as, carbon dioxide $\left(\mathrm{CO}_{2}\right)$, methane $\left(\mathrm{CH}_{4}\right)$, nitrous oxide $\left(\mathrm{N}_{2} \mathrm{O}\right)$ and ozone $\left(\mathrm{O}_{3}\right)$, which have been considered a major cause of global warming and climate change (Seo and Kim, 2013; Clark et al., 2016).

Some researches that used LCA for organic waste disposal have found that composting had less environmental impacts, than landfill or incineration (Andersen et al., 2012; Lundie and Peters, 2005). However, composting can have negative environmental impacts regarding $\mathrm{CO}_{2}$ emissions (during transport and processing equipments), and emissions of $\mathrm{CH}_{4}, \mathrm{~N}_{2} \mathrm{O}$ and $\mathrm{NH}_{3}$ from methanogenic and denitrification process, if anaerobic conditions occur in the composting process (odor and greenhouse gas emissions) according to Boldrin et al. (2009). The work of Saer et al. (2013) highlighted the importance of minimizing life cycle impacts associated with these emissions during the decomposition process, such as keeping the C:N ratio above 25 and below 35 (Carbon/ Nitrogenous ratio); maintaining a moisture content of $50-60 \%$; keeping a temperature range between 40 and $60^{\circ} \mathrm{C}$; and using in -vessel system, or other air delivery system.

The collection, transportation and disposal of organic waste require a large amount of fossil fuels, producing large quantities of GHG. Therefore, it is necessary to gauge how much GHG are emitted and in which steps (collection, transportation, and disposal) in order to gain a better understanding of the processes involved in GHG emission. Such understanding would make it possible to devise ways to properly dispose of these wastes, reducing the transportation-generated emissions through home composting incentives (UNFCCC, 2014).

Considering environmental impacts, the aim of the present study was to examine six alternatives to the composting of organic waste generated in the city of Bauru, in São Paulo, which currently does not have either a composting plant or a planning for home composting development in the future. For this purpose seven scenarios were considered: 1) sending organic waste to landfill in Bauru (base); 2) shipping the organic waste to another city that has a composting plant; 3 ) building a composting plant in the city of Bauru; 4) using home composting for $10 \%$ of organic waste; 5) using home composting for $25 \%$ of organic waste; 6 ) using home composting for $60 \%$ of organic waste; and 7) using home composting for $90 \%$ of organic waste. In each alternative, the amount of environmental impact was estimated.

\section{Methods}

This study had three methodological steps, described as follow. The first step consisted of literature review on the subject "composting" in the database of Scopus, Science Direct and Web of Science, in order to obtained alternatives in the literature for composting of organic waste generated in the city of Bauru, in São Paulo. The second step was to develop the scenarios for the management of the organic waste disposal.

Through interviews with the operators of EMDURB (Empresa Municipal de Desenvolvimento Urbano e Rural de Bauru Municipal Company for the Rural and Urban Development of Bauru), company responsible for waste collection, it was obtained information regarding the vehicles used in the transportation, the amount of organic waste collected (\%), the fraction of waste collected, the mileage $(\mathrm{km})$ traveled in the city due to the collection, and the operational costs of the transportation and landfill.

For the calculations of diesel consumption, transport capacity and greenhouse gas emissions, the following parameters were adopted: a compactor truck with 8.5 ton of load capacity, and an amount of approximately 113.66 ton/day of collected and transported organic waste.

The following options were considered:

\subsection{Scenario 1: base scenario - shipping the organic waste to the municipal landfill}

The Municipal Health Landfill, situated in the countryside, about $15 \mathrm{~km}$ from the city center, is in unsatisfactory situation. After 21 years of use, the Bauru landfill is near the limit of its capacity.

Studies are being carried out and will be completed by the end of 2016, so that the city is able to find the best approach concerning the landfill. Options vary from the expansion of the existing landfill, to the increase in the height of the last layer after leveling (heightening). Additionally, the reduction of the volume of waste disposed at the landfill could ensure some more useful life to the site. For this reduction to take place, public awareness needs to be stressed and an expansion in the selective collection coverage area and in the number of recyclable cooperatives is necessary, as well as ensuring adequate space and trained staff to carry out the composting of organic waste.

Organic waste generated in the city is dispatched almost in its entirety to the landfill. In Bauru, the collection of waste covers an average of $42 \mathrm{~km} /$ day by collecting sector. Currently there are 58 sectors, yielding a total of $2436 \mathrm{~km}$ per day of collection. The collection of wet waste occurs 3 times a week, in alternating days, with a total of 156 days per year. The distance traveled to and from the landfill is a route of $30 \mathrm{~km}$, which multiplied by the number of trips (14), is equal to $420 \mathrm{~km}$. In this case, the total distance traveled is of $2856 \mathrm{~km} /$ day. The total amount of fuel consumption (diesel) averages 82,989.57 L/year for a fleet of 17 compactor trucks, currently in use in the city of Bauru for collection of household waste.

For the first scenario, which represents the current situation in the city of Bauru, all the solid household waste generated in the 
municipality is collected and disposed of in the municipal landfill, without any kind of treatment or sorting. The amount of waste generated in Bauru is $0.850 \mathrm{~kg} /$ person/day, translating to an annual total of $310.3 \mathrm{~kg} /$ person/year (EMDURB, 2014). Considering that the city has 343,937 inhabitants, and an average of 3.1 inhabitants/ household, the total waste input for this scenario is: 19,744 ton of paper (18.49\%), 1708 ton of glass (1.62\%), 846 ton of ferrous metal (0.82\%), 221 ton of non-ferrous metal $(0.21 \%), 12,519$ ton of film plastic (11.74\%), 6478 ton of rigid plastic (6.05\%), 30,843 ton of organic material (28.93\%), and 34,365 ton of others $(32.14 \%)$, totaling 106,724 (100\%) ton of waste per year.

According to EMDURB (2014), 6\% of the waste generated in the household is sorted out by the inhabitants prior to being collected for recycling. The waste to be recycled is collected by cooperatives, and even though there is a lack of reported information by the cooperatives, the impacts of the recycling process were estimated using the IWM-2 software. Thus, the waste collected that remains after separation for recycling amounts to 18,557 ton of paper, 1608 ton of glass, 802 ton of ferrous metal, 210 ton of non-ferrous metal, 11,764 ton of film plastic, 6090 ton of rigid plastic, 30,843 ton of organic waste, and 34,365 ton of others (note that organics and others are not recyclable wastes).

The cost used for landfill operations was R\$50.5/ton (US\$ 15.00/ ton), and the cost of transportation, R\$ 99.11/ton (US\$ 30.00/ton). No hazardous waste is considered because the collection of this residue is done by another company, and it is incinerated. Also $290 \mathrm{~m}^{3}$ of leach are produced per month in the landfill according to data provided by EMDURB.

\subsection{Scenario 2: shipping the organic waste generated in the city of Bauru to the closest municipality having a composting plant}

The nearest town having an operational composting plant is the municipality of Garça, located $76.7 \mathrm{~km}$ (approximately $1 \mathrm{~h}$ drive) from Bauru. In this simulation, it was considered that the household waste is sorted at the landfill in Bauru and $90 \%$ of the organic waste is sent to the composting plant located in Garça city and 10\% are sent to the landfill. It was assumed that a truck with 40 ton of payload, that would make 3 travels per day of collection to transport 113.66 ton/day of organic waste, was used. This would add $460.2 \mathrm{~km}$ to the total distance traveled considered in alternative 1 $(2856 \mathrm{~km})$, totaling $3316.2 \mathrm{~km}$ per day of collection. Fuel consumption (diesel) around 96,223 L/year was estimated. Also it was estimated that $10 \%$ of the organic waste is rejected when sent to the Garça Landfill. The waste input is the same as in alternative 1, with a total of 106,724 ton.

\subsection{Scenario 3: building a composting plant in Bauru}

According to the Department of Agriculture and Food Supply of the City of Bauru (DAC), the municipality does not have a composting plant. Its implementation is in project preparation, with no cost figures for its construction available at the moment. Local government has been trying to enable the construction of a screening and composting plant in the city, seeking funds from the federal government and relevant agencies.

In line with available information, the creation of the plant in an area near the Municipal landfill, which is located in a rural area $15 \mathrm{~km}$ from the city center, is still being studied. And planning for experimentally deploying composting of organic waste discarded by the Warehouse Company and General Warehouses of São Paulo (CEAGESP) in Bauru is also under consideration. The municipal department already has the resources to build a shed to start this experience and begin producing organic fertilizer.

For this simulation the distance to be covered with waste collection and transport to the plant, with its implementation, would be the same as that of alternative 1, that is $2856 \mathrm{~km} /$ day, and it was considered that $10 \%$ of the organic waste sent to the Composting Plant was left as untreated residue. The waste input is still 106,724 ton, with the same percentage composition.

\subsection{Scenario 4 to 7: home composting}

Home composting, used for small quantities of waste is an important alternative in regions that do not have the composting process, as in Bauru.

The process has many advantages, such as reducing the amount of waste sent for composting plants and landfills, reducing the costs with collection service and transport of waste, reduction of environmental impacts caused by the transport of waste, reduction of the environmental impact caused by manure produced by the deposition of organic material in landfills, as well as having low operating costs. Some composter models are small and take up little space, making them ideal for small households and apartments. They can also be handcrafted with low-cost or out of nolonger-useful materials such as tires, plastic bottles, cans, plastic containers, etc. (Colón et al., 2010).

Several companies sell home-composters for households, schools and industries. Their prices range from R $\$ 120.00$ (US\$ 40.00 ) to R $\$ 290.00$ (US\$ 97.00) and some composters come with all the materials that will be needed for composting waste, such as earthworms, topsoil, compost and sawdust, all of which are low cost materials as well.

The capacity of these composters ranges from $0.5 \mathrm{~L} / \mathrm{day}$ (composting for one person) to $2 \mathrm{~L}$ /day (5 persons). At the end of a month, the composter for one person composts $15 \mathrm{~kg}$ of organic waste, whereas the composter for 5 people avoids $60 \mathrm{~kg}$ of waste from being dispatched to the landfill. Annually this translates to $180 \mathrm{~kg}$ (a person) and $720 \mathrm{~kg}$ ( 5 people) of residue that is not sent to the landfill.

For alternative 4 it was set the scenario where $10 \%$ of the organic waste is home-composted and $90 \%$ is collected and sent, along with the non-organic waste, to the Bauru Landfill, with a total of $301.3 \mathrm{~kg} /$ person/year of waste being collected. The estimated gravimetric percentages for this scenario for waste input were: paper (19.0\%), glass (1.67\%), metal (1.03\%), plastic (18.3\%), organic material (26.8\%), and others (33.1\%), totaling 103,628 (100\%) ton of waste (excluding the $10 \%$ of organic waste that are homecomposted per year).

For alternative 5 , it was set the scenario in which $25 \%$ of the organic waste is home-composted and $75 \%$ is sent to the Bauru Landfill, together with the non-organic waste. In this way, $287.9 \mathrm{~kg} /$ person/year of waste would be collected and sent to the landfill, with the following gravimetric percentage estimates for waste input: paper (19.9\%), glass (1.74\%), metal (1.11\%), plastic $(19.2 \%)$, organic material (23.4\%), and others (34.6\%), totaling 99,019 (100\%) ton of waste (excluding the $25 \%$ of organic waste that are homecomposted per year)

Similarly, for alternative 6 it was set the scenario where $60 \%$ of the organic waste is home-composted and $40 \%$ is sent to the Bauru Landfill, together with the non-organic waste. Thus, $256.5 \mathrm{~kg} / \mathrm{per}-$ son/year of waste would be collected and sent to the landfill, with the following gravimetric percentage estimates: paper $(22.4 \%)$, glass $(1.94 \%)$, metal (1.21\%), plastic $(21.5 \%)$, organic material $(14.0 \%)$, and others (34.4\%), totaling $88,218(100 \%)$ ton of waste (excluding the $60 \%$ of organic waste that are home-composted per year).

Lastly, for alternative 7 it was set the scenario where $90 \%$ of the organic waste is home-composted and $10 \%$ is sent to the Bauru Landfill, together with the non-organic waste. In this scenario, $229.6 \mathrm{~kg} /$ person/year of waste would be collected and sent to the 
landfill, with the following gravimetric percentage estimates for waste input: paper (25.0\%), glass (2.16\%), metal (1.35\%), plastic (24.1\%), organic material (3.90\%), and others (43.5\%), totaling $78,965(100 \%)$ ton of waste (excluding the $90 \%$ of organic waste that are home-composted per year).

It was considered that the number of collection days (3 days/ week) and fuel consumption (82,989.57 L/year) would remain the same for all alternatives.

The third step consisted of the elaboration of the LCI using the software IWM-2. According to Franke et al. (2003), the purpose of the software is to predict the environmental burdens of a specific waste management system, as accurately as possible, and considering all the possible functional units, such as waste input, waste collection and sorting, biological treatment, thermal treatment, landfilling, and energy generation. In this study, the functional units considered were waste input, waste collection and sorting, biological treatment (in alternative scenarios 2 and 3), and landfilling. This software was chosen because it requires few inputs of primary data, namely the population of the area under study, the number of households served, the amount of waste generated (in $\mathrm{kg} /$ person/year), the detailed composition of the waste (in \% by weight), the energy input, the operational costs, and the efficiency of the processes considered in each scenario.

Also, in alternatives 4 to 7 , for the home composting $\mathrm{LCI}$, the average values of Andersen et al. (2012), presented in Table 1, were added to the LCI results provided by IWM- 2, because it was beyond the capacity of the software to calculate the impacts due to home composting. In order to convert the values obtained in the LCI to environmental impacts, the conversion factors published by the ReCiPe2008 report (Heijungs et al., 2009) were used. While using this report, the environmental impacts were considered only at the midpoint level, because according to CETEA the data available for the endpoint (normalization of values) does not adequately represents the reality for waste management in Brazil. Also, the ReCiPe2008 report presents conversion factors based on three different perspectives: individualistic, hierarchist, and egalitarian. For the purpose of this study, the hierarchist perspective was adopted, as it is an intermediate perspective that regards nature as tolerant, considers only likely effects on the environment, and has a preventive, rather than controlling, management style (De Schryver, 2010); all of which fit the authors' vision of waste management.
The system boundary for each scenario is presented in Fig. 1 and Fig. 2. In general, the boundaries consist of the input of both waste, more specifically solid household waste, and fuel (for the collection/transportation of such waste). Within the systems, there are four possible processes: home recycling (present in all scenarios), dispatch to landfill (present with different amounts in all scenarios), composting plant (present in scenarios 2 and 3), and home composting (present in scenarios 4 to 7). Finally, at the output stage, there are several emissions to the environment, whose impacts are then measured.

\section{Results and discussion}

This section presents the analysis of seven scenarios for the final disposition of organic waste in the city of Bauru, focusing on the following impact categories: climate change (gaseous emissions); particulate matter formation; ozone depletion; water and human toxicity (water and air emissions).

\subsection{Climate change impact}

The climate change impact was determined based on the mass emission (in $\mathrm{kg}$ ) of three gases: $\mathrm{N}_{2} \mathrm{O}, \mathrm{CH}_{4}$ and $\mathrm{CO}_{2}$. These emissions were transformed into $\mathrm{CO}_{2}$ eq. $(\mathrm{kg})$ using the ReCiPe2008 equivalent factors at the midpoint level (hierarchist perspective). As Fig. 3 shows, in this category the emissions of $\mathrm{CH}_{4}$ have the most significant impact in all scenarios, figuring as an average (for all seven scenarios) of $90 \%$ of the impact generated by the three gases considered. Scenarios 2 and 3 have similar results, as both considered the dispatch of $90 \%$ of the organic waste to composting plants, and had the least impact when compared to almost all scenarios, losing only to scenario 7 (90\% of home composting), which had $48 \%$ less impact than Scenario 1, which represents the current situation in Bauru. Scenarios 4 to 7 had fewer $\mathrm{CH}_{4}$ emissions than Scenario 1, nevertheless, they had significantly greater emissions of $\mathrm{N}_{2} \mathrm{O}$ (which increased with the amount of home composting from $0.32 \%$ to $5.2 \%$, respectively from scenario 4 to 7 ). All scenarios had relatively the same emission of $\mathrm{CO}_{2}$ with a slightly increase for scenarios 6 and 7. Our findings with regards to the higher emissions of $\mathrm{N}_{2} \mathrm{O}$ in home composting scenarios are in agreement with the study of Andersen et al., 2012.

Table 1

LCI data for home composting of organic household waste. Adapted from Andersen et al. (2012).

\begin{tabular}{|c|c|c|c|}
\hline & LCI data & Amount & Unit \\
\hline Input waste & Organic household waste & $68-90$ & $\mathrm{Kg}_{\mathrm{ww}}$ year $^{-1}$ \\
\hline \multirow[t]{2}{*}{ Energy and materials consumption } & Electricity & 0 & $\mathrm{kWh} \mathrm{Mg}^{-1} \mathrm{wW}$ \\
\hline & Water & 0 & $\mathrm{~L} \mathrm{Mg}^{-1}$ ww \\
\hline \multirow[t]{3}{*}{ Gaseous emissions (to atmosphere) } & $\mathrm{CO}_{2}-\mathrm{C}$ (biogenic) & 215 & $\mathrm{Kg} \mathrm{Mg}^{-1} \mathrm{ww}$ \\
\hline & $\mathrm{CH}_{4}-\mathrm{C}$ & 2.3 & $\mathrm{Kg} \mathrm{Mg}^{-1} \mathrm{ww}$ \\
\hline & $\mathrm{N}_{2} \mathrm{O}-\mathrm{N}$ & 0.43 & $\mathrm{Kg} \mathrm{Mg}^{-1} \mathrm{ww}$ \\
\hline \multirow[t]{14}{*}{ Liquid emissions (to groundwater) } & Leachate generation & 130 & $\mathrm{~L} \mathrm{Mg}^{-1} \mathrm{ww}$ \\
\hline & Total N losses & 0.05 & $\mathrm{Kg} \mathrm{Mg}^{-1} \mathrm{ww}$ \\
\hline & Total C losses & 0.33 & $\mathrm{Kg} \mathrm{Mg}^{-1} \mathrm{ww}$ \\
\hline & BOD & 3.5 & $\mathrm{Kg} \mathrm{Mg}^{-1} \mathrm{ww}$ \\
\hline & COD & 9.9 & $\mathrm{Kg} \mathrm{Mg}^{-1} \mathrm{ww}$ \\
\hline & $\mathrm{K}$ & 6.4 & $\mathrm{Kg} \mathrm{Mg}^{-1} \mathrm{ww}$ \\
\hline & $\mathrm{P}$ & 0.08 & $\mathrm{Kg} \mathrm{Mg}^{-1} \mathrm{ww}$ \\
\hline & As & $2.4 \cdot 10^{-5}$ & $\mathrm{Kg} \mathrm{Mg}^{-1} \mathrm{ww}$ \\
\hline & $\mathrm{Cd}$ & $2.5 \cdot 10^{-6}$ & $\mathrm{Kg} \mathrm{Mg}^{-1} \mathrm{ww}$ \\
\hline & $\mathrm{Cr}$ & $3.2 \cdot 10^{-5}$ & $\mathrm{Kg} \mathrm{Mg}^{-1} \mathrm{ww}$ \\
\hline & $\mathrm{Cu}$ & $2.9 \cdot 10^{-4}$ & $\mathrm{Kg} \mathrm{Mg}^{-1} \mathrm{ww}$ \\
\hline & $\mathrm{Hg}$ & $2.8 \cdot 10^{-7}$ & $\mathrm{Kg} \mathrm{Mg}^{-1} \mathrm{ww}$ \\
\hline & $\mathrm{Ni}$ & $8.7 \cdot 10^{-5}$ & $\mathrm{Kg} \mathrm{Mg}^{-1} \mathrm{ww}$ \\
\hline & $\mathrm{Pb}$ & $9.9 \cdot 10^{-5}$ & $\mathrm{Kg} \mathrm{Mg}^{-1} \mathrm{ww}$ \\
\hline
\end{tabular}




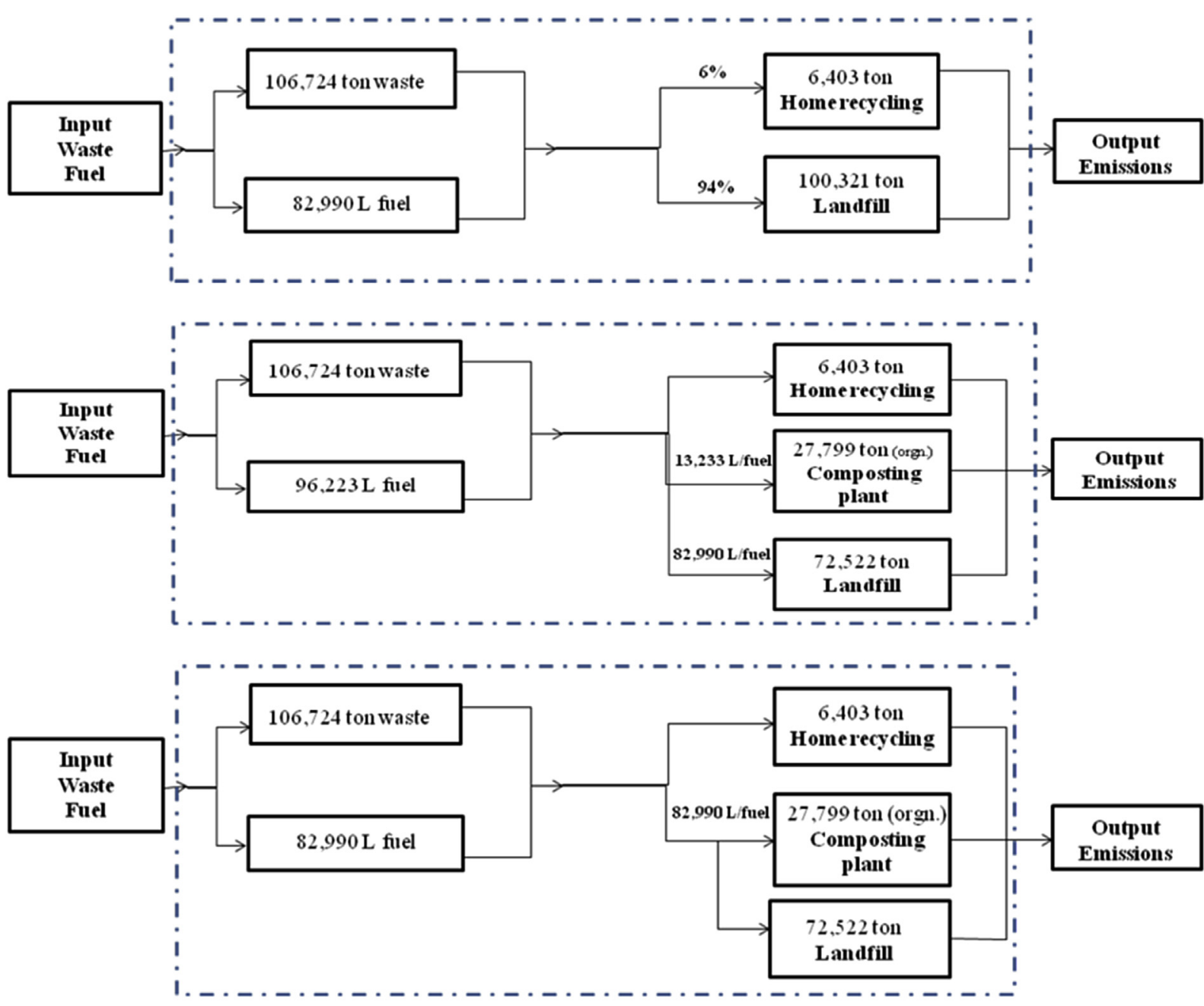

(a)

Fig. 1. System boundary: (a) scenario 1; (b) scenario 2; (c) scenario 3.

\subsection{Ozone depletion}

The impact on the ozone layer was determined based on the mass of CFC11 eq. ( $\mathrm{kg}$ ) of chlorinated hydrocarbons using the equivalent factors found in the ReCiPe2008 report, as shown in Fig. 4. Scenarios 6 and 7 had the lowest impacts of all seven scenarios, with a reduction of $37.5 \%$ and $46.3 \%$ in the ozone depletion impact, respectively, when compared to Scenario 1 . Scenarios 4 to 7 show the potential of home composting in reducing the impact in ozone depletion, being that scenario 6 (60\% of home composting) had results similar to those of composting plants (Scenarios 2 and 3 ) and scenario 7 was the one with the least impact on the ozone layer.

\subsection{Particulate matter formation}

The particulate matter formation was determined in PM10 - eq. (kg). Particulate matter has a series of chemical substances in particle form that, from a toxicological standpoint, contributes to an increase in the occurrence of respiratory diseases, and that from an environmental perspective, causes damage to vegetation and soil contamination. Overall, the substances that most contribute to this impact are nitrogen oxides $\left(\mathrm{NO}_{\mathrm{x}}\right)$ in scenarios 1 to 4 ; the most significant impact when considering the emission of $\mathrm{NO}_{\mathrm{x}}$ was seen in scenarios 2 and 3. In cases where there is home composting (scenarios 4 to 7 ), the impact due to $\mathrm{N}_{2} \mathrm{O}$ becomes considerable as well, and from scenario 5 to 7, it becomes the substance that most contributes. The impact caused by $\mathrm{NH}_{3}$ in all scenarios is similar, with the less impact where the composting plants were considered (scenarios 2 and 3). One interesting aspect to notice, as shown in Fig. 5, is that for scenarios 2 and 3 the particulate and the sulfur oxides are emitted, whereas in all other scenarios, these substances are absorbed.

\subsection{Freshwater toxicity}

For freswater toxcity the characterisation factors are expresssed using the reference unit of $\mathrm{kg}$ of 1,4 - dichlorobenzene eq. (1,4-DB). In this impact category the selected metals that contributed the most were nickel and copper from water emissions (Fig. 6), and in the composting plant scenarios mainly nickel from air emissions (Fig. 7). Scenarios 2 and 3 (composting plants) had the greatest impact on freshwater toxity from air emissions. In regards to scenarios 4 to 7 (home composting), it is observed that they have similar results than scenario 1 for air emission, showing that the ecotoxicity from air emissions of home composting scenarios is better than or as good as emissions from landfilling scenarios. However this trend was not 


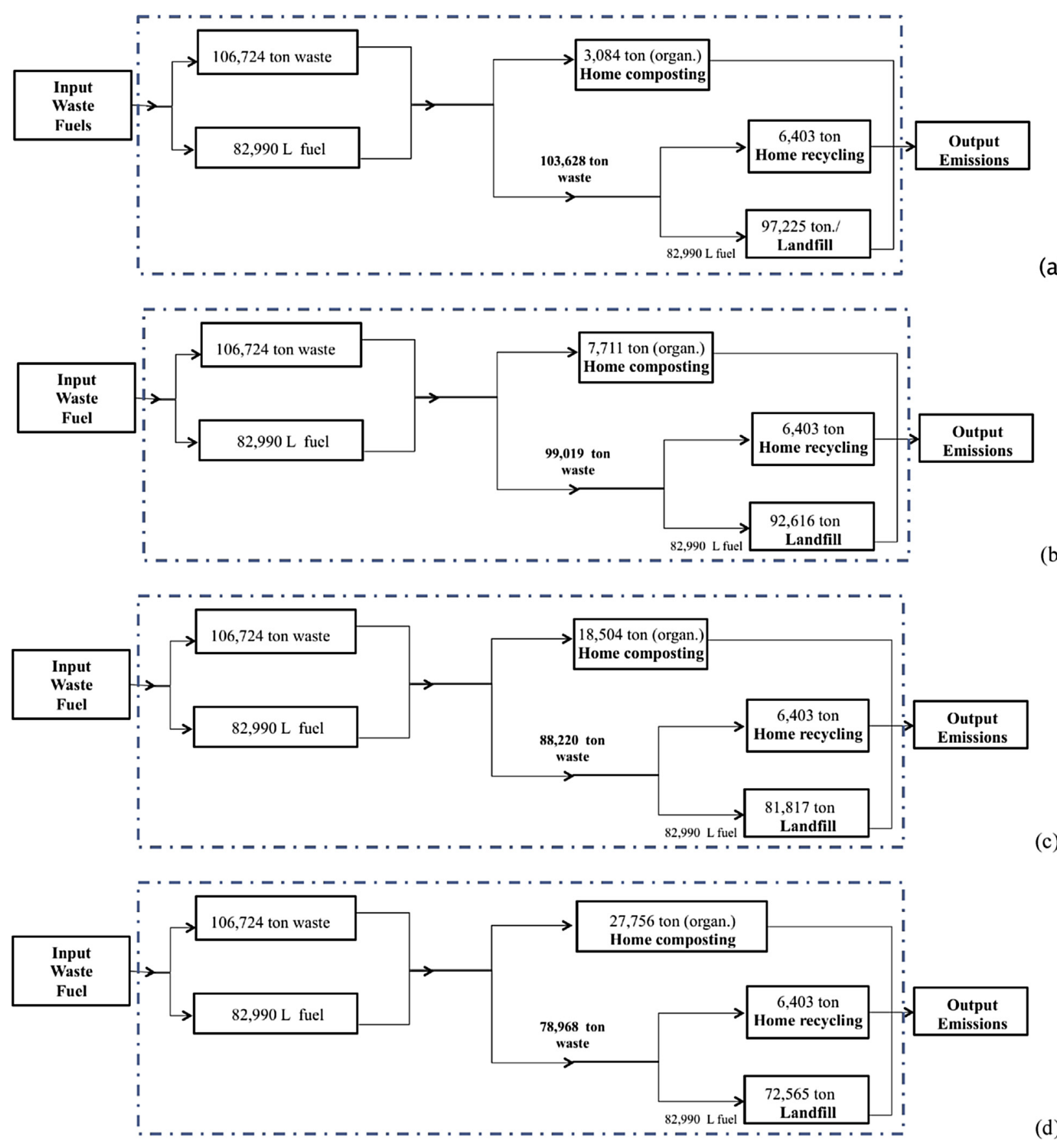

(a)

Fig. 2. System boundary for home composting: (a) scenario 4; (b) scenario 5; (c) scenario 6; (d) scenario 7.

observed for ecotoxicity from water emissions, where the presence of nickel and copper increases steadily from scenarios 5 to 7.

\subsection{Human toxicity potential (HTP)}

The assesment of toxicity is based on tolerable concetrations in air and water for acceptable daily human intake. For each toxic substance HTPs are expressed using the reference unit of $\mathrm{kg}$ of $1,4-$ dichlorobenze (1,4-DB) eq. The home composting scenarios (4-7) have the higher values of HTP from air emissions, with an average increase of $9.8 \%$ in comparison to scenario 1 . Scenarios 2 and 3 (composting plants) have the same HTP and, overall, the lowest values of HTP, with a reduction of $6.7 \%$ in regards to the base scenario (Fig. 8). The main air emission in all scenarios is of lead, followed by smaller amounts of mercury. In regards to the HTP from water emission, scenarios 6 and 7 had the highest values, with equivalent to 9 and 13 times, respectively, the impact of scenario 1 (Fig. 9). As the amount of waste composted at home composting increased, the emission of arsenic to water spiked. Findings by Andersen et al. (2012) show that the HTP from water emission is greater in home composting scenarios than in composting plant ones. Our results are partially in accordance with this, as home composting becomes more harmful than composting plant alternatives only above some 


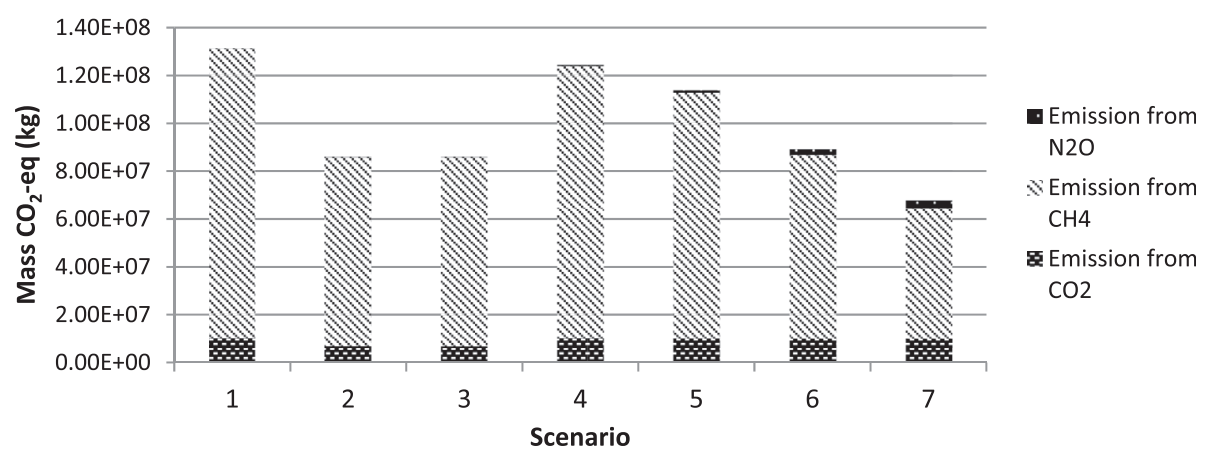

Fig. 3. Climate impact due to emissions of $\mathrm{CO}_{2}, \mathrm{CH}_{4}$, and $\mathrm{N}_{2} \mathrm{O}$.

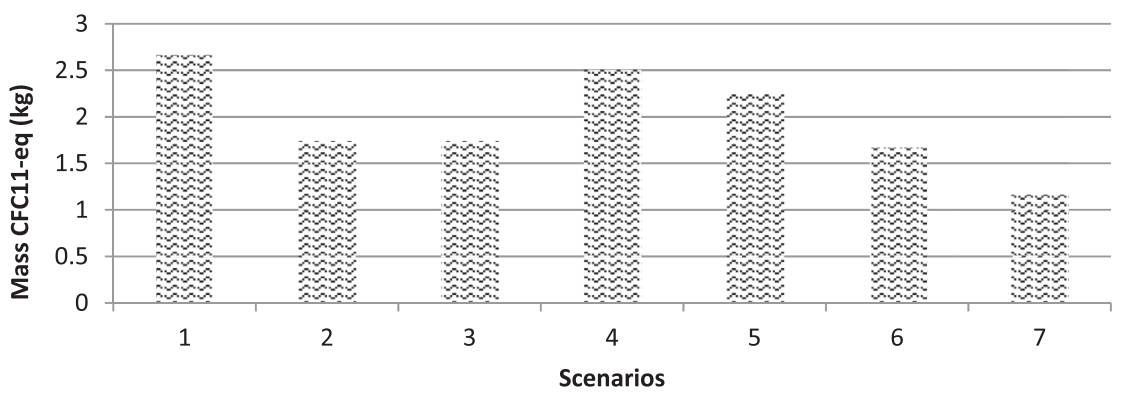

Fig. 4. Ozone depletion due to emission of chlorinated hydrocarbons.

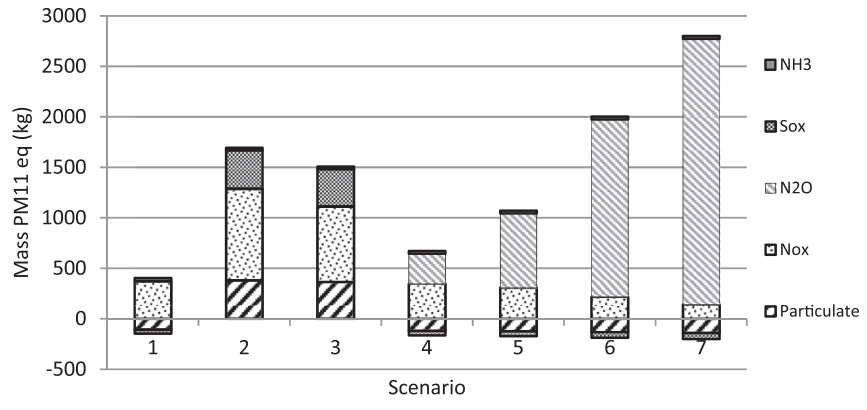

Fig. 5. Particulate matter formation impact.

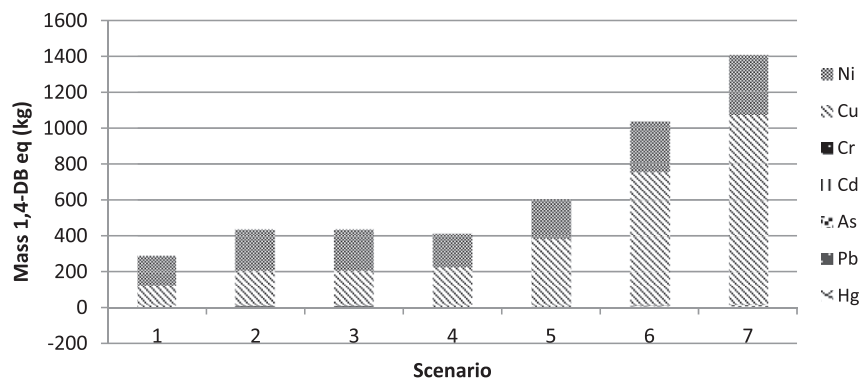

Fig. 6. Freshwater toxicity water emissions.

level of home composting, namely scenarios 6 and 7.

\section{6. $\mathrm{CO}_{2}$ emission by process}

In comparison with scenario 1 , all other scenarios presented less $\mathrm{CO}_{2}$ emission, in particular reductions of $31.7 \%$ (Scenario 2), $32.0 \%$ (Scenario 3), $1 \%-1.5 \%$ (Scenarios 4 to 6 ), and 2.3\% (Scenario 7), are

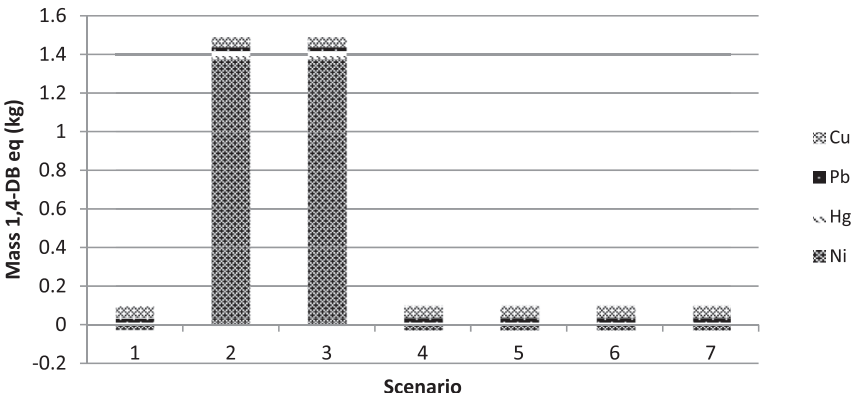

Fig. 7. Freshwater toxicity air emissions.

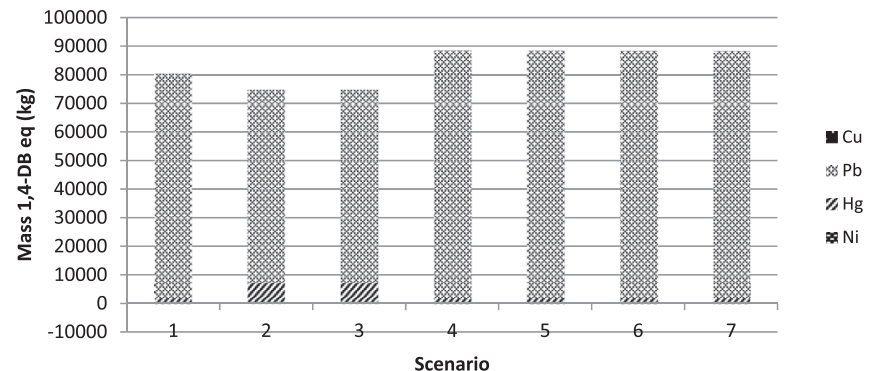

Fig. 8. Human toxicity potential from air emissions.

shown in Fig. 10. In addition, home composting reduced the amount of $\mathrm{CO}_{2}$ emitted in the landfill process gradually by $6.18 \%$ for each $10 \%$ increase in home composting. Compared with scenario 1 , the amount of $\mathrm{CO}_{2}$ emitted during the biological treatment increased proportionally to the amount of home composting. The composting plant scenarios had less emission regarding the biological process when compared with the home composting 


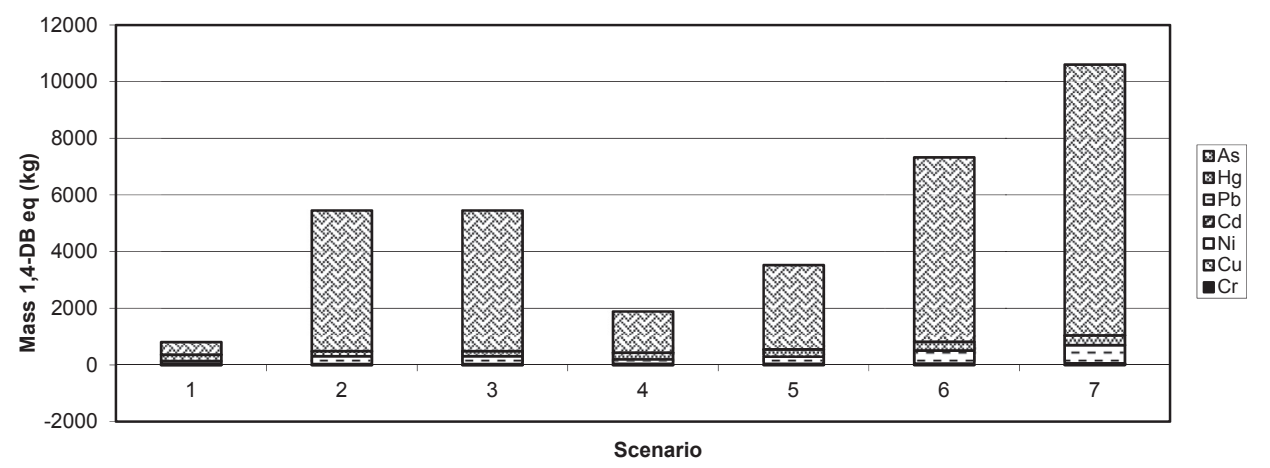

Fig. 9. Human toxicity potential from water emissions.

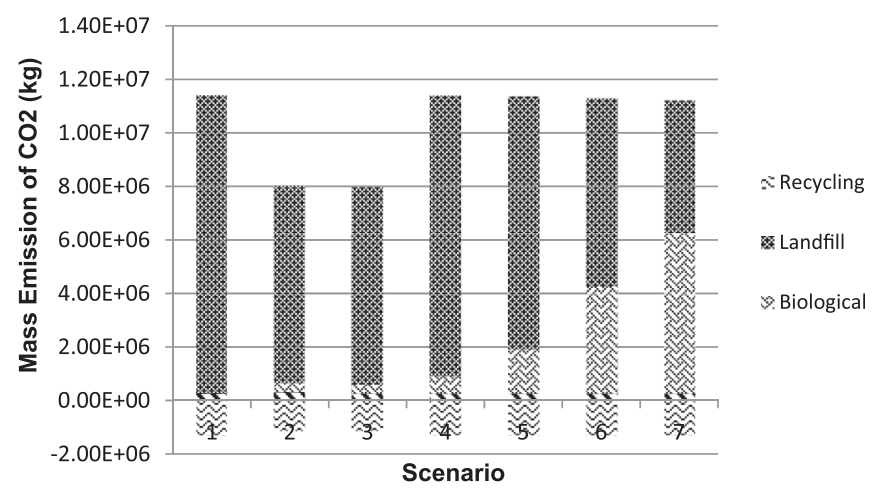

Fig. 10. $\mathrm{CO}_{2}$ emission by process.

scenarios. Scenario 7 which had the same amount of composting as scenarios 2 and 3 (90\%) had 16.6 times more emissions during the biological process. Despite home composting still being viable as an environmental alternative for organic waste disposal, it is suggested the development of new technologies regarding the home composter to address the emission of $\mathrm{CO}_{2}$ during the biological process. It is important to clarify that even though scenarios 4 to 7 did not present an absolute advantage in regards to $\mathrm{CO}_{2}$ emissions, these scenarios have decreasing emissions of $\mathrm{CH}_{4}$ (Fig. 3), with scenarios 6 and 7 having the lowest emissions of all scenarios. Also, in this paper it was not considered the manure or fertilizer substitution using the compost product, which can reduce the impact of the biological process. The majority of $\mathrm{CO}_{2}$ is liberated in the landfill, and the only process that consumes $\mathrm{CO}_{2}$ is recycling. One alternative to reduce the overall output of $\mathrm{CO}_{2}$ would be to increase the amount of waste that is recycled prior to being collected.

One last thing to consider is that reducing the number of collection days will motivate households to search for other means to dispose of organic waste, such as home composting. Thus, this reduction may initiate a virtuous circle to enhance home composting. This will be in line with the "zero waste" policy that implies a holistic approach towards waste management that encompasses environmental impacts (Zaman, 2015; Song et al., 2015) and societal awareness (Hottle et al., 2015).

\section{Conclusions}

Among the scenarios considered for composting of organic waste generated in the city of Bauru, the option to send the waste to another municipality, which has a composting plant in operation (municipality of Garça), was the one with the longest distance to be traveled in order to collect and transport the waste. However, in order to reduce this distance a transfer station with sorting of organic waste and transportation with a vehicle with more load capacity can minimize the total travel distance and its impacts. The environmental impact of scenarios 2 and 3 with composting plants in Garça and Bauru had similar results with less environmental impacts in human toxicity to air emissions when compared to the other scenarios. The composting plants also had one of the smallest impacts for climate change and ozone depletion. However, composting plants had a considerable increase in environmental impacts for particulate matter formation and freshwater ecotoxicity (air emissions) when compared to the base scenario. In this paper it was not taken into account the economic and environmental impacts of construction of the facilities for transfer and sorting the waste to Garça, the construction of a sorting facility and a composting plant in Bauru and the benefits of the final product produced in the composting process.

The composting plant had the advantage of extending the life of the Municipal landfill, which is already near the limit of its capacity, making it necessary to decrease the volume of the waste deposited in the site. As for the construction of the composting plant, it is an option that has been studied and designed by the city of Bauru, and that has the potential to be viable, since the city generates a large amount of organic waste.

To achieve $100 \%$ of home composting is utopist. But any amount of home composting is important to reduce the amount of organic waste that is sent to the landfill and to reduce the environmental impacts, specially the climate change and ozone depletion. In addition, it was found that home composting has a greater potential to reduce the $\mathrm{CO}_{2}$ equivalent emitted per mass of organic waste composted than composting plants. Nevertheless, a home composting policy that is not accompanied by a reduction in the household waste collection days will have a trifling impact on $\mathrm{CO}_{2}$ emissions from collection and transportation. It is also important to notice that, even though this aspect of home composting was revealed in this study, it was also found that home composting increases the emissions of gases that are more noxious in regards to the climate change than $\mathrm{CO}_{2}$ itself, namely $\mathrm{N}_{2} \mathrm{O}$.

Another aspect to consider is that home composting was beneficial in some categories only in certain amounts. For ozone depletion and climate change, for example, the greater the percentage of home composting, the greater the impact reduction from the base scenario. On the other hand, for particulate matter formation, freshwater toxicity from water emissions, and human toxicity from water, larger amounts of home composting presented a larger impact than the base scenario, specially for scenarios 6 and 7.

For further works it is indicated to perform a Life Cycle Assessment of all alternatives, which must include environmental 
impacts of construction of the transfer and sorting facilities and composting plant. In addition, more studies about the Life Cycle Inventory of home composting in different countries and regions should be further investigated.

\section{Acknowledgements}

The authors would like to thank the collaboration of EMDURB in this study and CAPES for the grant received for the development of this research.

\section{References}

Adhikari, B.K., Trémier, A., Barrington, S., Martinez, J., Daumoin, M., 2013. Gas emissions as influenced by home composting system configuration. J. Environ. Manage 116, 163-171.

Amlinger, F., Peyr, S., Cuhls, C., 2008. Greenhouse gas emissions from composting and mechanical biological treatment. Waste Manag. Res. 26, 47-60.

Andersen, J.K., Boldrin, A., Christensen, T.H., Scheutz, C., 2012. Home composting as an alternative treatment option for organic household waste in Denmark: an environmental assessment using life cycle assessment-modelling. Waste Manag. 32, 31-40.

Brasil, 2010. Law No 12. 305 of August 2, 2010: Establishes the National Policy on Solid Waste; Amending Law No. 9.605, of February 12, 1998; and Other Measures. Brasília, Brasil. Available in: http://www.planalto.gov.br/ccivil_03/_ Ato2007-2010/2010/Lei/L12305.htm (Portuguese)

Boldrin, A., Andersen, J. Møller, J., Christensen, T., 2009. Composting and compost utilization: accounting of greenhouses gases and global warning contributions. Waste Manag. Res. 27, 800-812.

Chanakya, H.N., Ramachandra, T.V., Guruprasad, M., Devi, D., 2007. Micro-treatment options for components of organic fraction of MSW in residencial areas. Enviromental Monit. Assess. 135, 129-139.

Clark, S., Knoshnvisani, B., Sefeedpari, P., 2016. Energy efficiency and greenhouse gas emissions during transition to organic and reduced-input practices: student farm case study. Ecol. Eng. 88, 186-194.

Cólon, J., Martinez-Blanco, J., Xavier, G., Artola, A., Sánchez, A., Rieradevall, J. Xavier, F., 2010. Environmental assessment of home composting. Resour. Conservation Recycl. 54, 893-904.

De Schryver, A.M., 2010. Value Choices in Life Cycle Impact Assessment. PhD -
Thesis. University, Nijnegen, Radboud.

Franke, M., Hindle, P., Mcdougall, F., White, P., 2003. Integrated Solid Waste Management: a Life Cycle Inventory. Editora Blackwell Science, UK.

Heijungs, R., Huijbregts, M., Schryver, A., Struijs, J., Zelm, R., 2009. ReCiPe 2008. A Life Cycle Impact Assessment MethCod Which Comprises Harmonised Category Indicators at the Midpoint and the Endpoint Level. First Edition, Netherlands. Available at: http://www.leidenuniv.nl/cml/ssp/publications/recipe characterisation.pdf. Accessed on April 2016

Hottle, T.A., Bilec, M.M., Brown, N.R., Landis, A.E., 2015. Toward zero waste: composting and recycling for sustainable venue based events. Waste Manag. 38, 86-94.

Lundie, S., Peters, G., 2005. Life Cycle assessment of food waste management options. J. Clean. Prod. 13, 257-286.

Martínez-Blanco, J., et al., 2010. The use of life cycle assessment for the comparison of biowaste composting at home and full scale. Waste Manag. 30, 983-994.

Martins, N.F., 2012. Model of organic composters at home environmental management. Rev. Bras. Gestão Ambient. - RBGA 6 (n. 1), 29-36.

EMDURB, 2014. Data for Diagnosis of Solid Waste Management. Department of Environment, Bauru (in Portuguese).

Saer, A., Lansing, S., Davitt, N.D., Graves, R.E., 2013. Life cycle assessment of a food waste composting system: environmental impact hotspots. J. Clean. Prod. 52, 234-244.

Scoton, E.J., Battistelle, R.A.G., Bezerra, B.S., Akutsu, J., 10 May 2016. A sewage sludge co-composting process using respirometric monitoring method in hermetic rotary reactor. J. Clean. Prod. 121, 169-175. http://dx.doi.org/10.1016/ j.jclepro.2015.04.081.

Seo, Y., Kim, S., 2013. Estimation of greenhouse gas emissions from road traffic: a case study in Korea. Renew. Sustain. Energy Rev. 28, 777-787.

Shen, Y., et al., 2012. Online monitoring of volatile organic compound production and emission during sewage sludge composting. Bioresour. Technol. 123, $463-470$

Silva, A.G., Leite, V.D., Silva, M.M.P., Prasad, S., Feitosa, W.B.S., 2009. Compostagem aeróbia conjugada de lodo de tanque séptico e resíduos sólidos vegetais. Rev. Eng. Sanitária Ambient. Rio J. 13 (n. 4), 371-379.

Song, Q., Li, J., Zeng, X., 2015. Minimizing the increasing solid waste through zero waste strategy. J. Clean. Prod. 104, 199-210.

UNFCCC, 2014. United Nations Convention on Climate Change - First Steps to a Safer Future : Introducing the United Nations Framework Convention on Climate Change [Online] Available at: https://unfccc.int/essential_background/ convention/items/6036.php.

Zaman, A.U., 2015. A comprehensive review of the development of zero waste management: lessons learned and guidelines. J. Clean. Prod. 91, 12-25. 